\title{
Avaliação dos valores séricos de cálcio ionizado pelo método eletrodo íon seletivo em cães hígidos
}

[Evaluation of serum ionized calcium by ion-selective electrode method in healthy dogs]

\author{
M.D. Lustoza ${ }^{1}$, M.M. Kogika ${ }^{2}$, P. Lazaretti ${ }^{3}$, R.M.S. Mirandola ${ }^{2}$ \\ ${ }^{1}$ Mestrando em Clínica Veterinária - FMVZ-USP \\ ${ }^{2}$ Departamento de Clínica Médica - Faculdade de Medicina Veterinária e Zootecnia \\ Universidade de São Paulo \\ Av. Prof. Dr. Orlando Marques de Paiva, 77 \\ 05508-000 - São Paulo, SP \\ ${ }^{3}$ Médica Veterinária. Mestre em Clínica Veterinária
}

\begin{abstract}
RESUMO
Avaliou-se a concentração sérica de cálcio ionizado, pelo método eletrodo íon-seletivo, em 40 cães sadios, para compará-la aos valores obtidos por meio do cálcio ionizado estimado em que se considerou a metade do valor do cálcio total mensurado pelo método colorimétrico e corrigido pela albumina. Não foi observada diferença do cálcio ionizado entre os dois métodos e observou-se baixa correlação entre os métodos $(\mathrm{r}=0,328)$.
\end{abstract}

Palavras-chave: cão, eletrodo íon-seletivo, cálcio ionizado

\begin{abstract}
Serum ionized calcium concentrations were evaluated by ion-selective electrode method in 40 healthy dogs and compared to ionized calcium estimates obtained considering the half value of corrected total calcium, measured by colorimetric method. No difference was observed between ionized calcium obtained by both methods and low correlation was estimated $(r=0.328)$ between the methods.
\end{abstract}

Keywords: dog, ion-selective method, ionized calcium

\section{INTRODUÇÃO}

O cálcio presente no sangue é formado por três frações: cálcio ionizado, cálcio ligado a proteínas séricas e cálcio complexado a ânions. O cálcio ionizado é a fração mais importante do ponto de vista biológico, representando cerca de $50 \%$ do cálcio total, pois desempenha a função de íon regulador em muitos processos metabólicos (Duncan e Prasse, 1986; Sena e Bowers, 1988; Bush, 1991; Nelson et al., 1994).
Rotineiramente, o metabolismo do cálcio é avaliado por meio da determinação do cálcio sérico total. Em algumas condições mórbidas, como nos pacientes acometidos por alguns tipos de neoplasias ou em estágio final de doença renal, nas quais pode ocorrer alteração na proporção das frações do cálcio, somente a mensuração do cálcio ionizado pode fornecer uma avaliação precisa da fração do cálcio biologicamente ativa (Bowers et al., 1986; Sena e Bowers, 1988; Schenck et al., 1995; Rosol e Capen, 1996; Schenck e Chew, 2003).

Recebido para publicação em 15 de outubro de 2003

Recebido para publicação, após modificações, em 20 de maio de 2004

Trabalho realizado sob os auspícios da FAPESP (Proc. 99/00854-0)

E-mail: mmkogika@usp.br 
Vários fatores podem influenciar a proporção da fração do cálcio ionizado, sendo os mais importantes a concentração de proteínas sérica e albumina, o $\mathrm{pH}$ do sangue e a temperatura corporal (Sena e Bowers, 1988). Na tentativa de estimar o grau de interferência desses fatores na avaliação de laboratório do cálcio, foram desenvolvidas fórmulas de correção, sendo a mais utilizada a que considera a concentração sérica de albumina na correção do valor do cálcio total. Nenhuma fórmula mostrou-se totalmente eficaz para estimar, de forma adequada, à concentração sérica de cálcio ionizado (Sena e Bowers, 1988; Schenck et al., 1995; Rosol e Capen, 1996).

Somente com o advento do eletrodo íon-seletivo foi possível analisar, com maior confiabilidade, os valores de cálcio ionizado, pois esse método não é sensível ao cálcio ligado a proteínas e a outros compostos (Sena e Bowers, 1988). Embora a tecnologia e a disponibilidade dos analisadores com eletrodo íon-seletivo tenham aumentado, ainda é um método pouco utilizado para a avaliação do metabolismo do cálcio em medicina veterinária (Schenck e Chew, 2003).

O objetivo do presente estudo foi determinar a concentração sérica de cálcio ionizado em cães hígidos pelo método eletrodo íon-seletivo e comparar os valores obtidos com aqueles determinados pelo método colorimétrico, considerando-se $50 \%$ do valor do cálcio total corrigido.

\section{MATERIAL E MÉTODO}

Foram utilizados 40 cães hígidos, em domicílios, não castrados, com ou sem definição racial, avaliados por anamnese, exame físico, hemograma, exame de urina, bioquímica sérica (uréia, creatinina, proteína total e albumina) e hemogasometria. Os animais, com idades entre 1 e 12 anos, foram divididos em grupos de 10 animais nas seguintes faixas etárias: 1 a 3,3 a 6 , 6 a 9 e 9 a 12 anos.

De cada animal foi colhida uma amostra de sangue pela punção das veias cefálica, radial ou jugular, após jejum alimentar de aproximadamente oito horas, sempre entre 9 e $10 \mathrm{~h}$ da manhã. O sangue foi acondicionado em tubos a vácuo, isentos de íons com gel separador $^{1}$, preenchendo pelo menos $70 \%$ do volume do frasco, e imediatamente centrifugado durante cinco minutos a $1700 \mathrm{~g}$. $O$ frasco foi mantido fechado (em anaerobiose) até a determinação do cálcio sérico ionizado pelo método eletrodo íon-seletivo, utilizando-se analisador eletrodo íon-seletivo ${ }^{2}$, realizada em até 30 minutos após a colheita de sangue.

O cálcio sérico total foi mensurado pelo método colorimétrico com cresolftaleína (Sarkar et al., 1967), utilizando-se analisador automático ${ }^{3}$. Para o cálculo da correção do cálcio total e da porcentagem estimada de cálcio ligado à proteína foram utilizados os valores séricos de albumina de acordo com a fórmula: cálcio total corrigido $=$ (cálcio total - albumina) $+3,5 \times 0,5$ (Feldman, 1995; Portale, 1996). A albumina foi determinada pelo método de verde de bromocresol segundo Doumas-Biggs modificado (Watson et al., 1971), em analisador automático ${ }^{3}$.

A hemogasometria do sangue venoso foi realizada utilizando-se aparelho analisador de gases $^{2}$. O sangue foi colhido em seringas contendo heparina de sódio e lítio balanceada ${ }^{4}$.

Para verificar se os valores de cálcio obtidos apresentavam distribuição normal foi utilizado o teste de Kolmogorov-Smirnov $(\mathrm{P}<0,05)$. Usou-se o teste não paramétrico de Mann-Whitney para comparação de médias do cálcio ionizado obtidas pelos dois métodos, considerando-se $50 \%$ do valor do cálcio total corrigido e calculou-se o coeficiente de correlação (r) entre os valores de cálcio obtidos pelo método eletrodo íon-seletivo e os calculados a partir de $50 \%$ do valor do cálcio total corrigido. Foram utilizados os programas estatísticos Stata TM versão 5.0 e InSTAT, versão 2.01, segundo Sampaio (1998).

\section{RESULTADOS E DISCUSSÃO}

A concentração sérica de cálcio ionizado, obtida de cães sadios que apresentaram temperatura corporal normal, e as variáveis da hemogasometria, dentro dos valores de referência, mostraram que a média, a mediana e

\footnotetext{
${ }^{1}$ Tubo Vacutainer ${ }^{\circledR}$ SST, Becton Dckinson, Plymouth, UK.

${ }^{2}$ OMNI 4, AVL Medical Instruments, Graz, Austria.

${ }^{3}$ RA-100 Clinical Analyser, Technicon ${ }^{\circledR}$, New York, USA.

${ }^{4}$ COMBI -sampler® - Vented syringe kits, AVL Medical

Instruments, Graz, Austria.
} 
os percentis foram semelhantes aos valores obtidos a partir de $50 \%$ do valor de cálcio total corrigido pela albumina sérica (Tab. 1). Entretanto, apesar dos valores de cálcio ionizado obtidos pelos dois métodos não serem significativamente diferentes $(\mathrm{P}=0,368)$, observou-se grande variação dos valores individuais calculados a partir de $50 \%$ do valor do cálcio sérico total (Fig. 1), confirmada pela baixa correlação observada entre os dois métodos $(\mathrm{r}=0,328 ; \mathrm{P}=0,039)$.

Face ao número crescente de afecções que envolvem o metabolismo de cálcio, a avaliação do cálcio ionizado poderia trazer informações relevantes para o reconhecimento dos distúrbios, e somente o valor de cálcio ionizado obtido a partir de $50 \%$ do valor do cálcio total poderia levar a interpretações errôneas (Sena e Bowers, 1988), pois esse valor é obtido a partir de cálculos do nomograma em que não são considerados fatores importantes como $\mathrm{pH}$, temperatura e concentração sérica de albumina, que podem influenciar na fração de cálcio ionizado disponível (Finco, 1983; Portale, 1996; Sutton e Dirks, 1996).

Tabela 1. Média, mediana, desvio-padrão da média, erro-padrão da média, valores mínimo e máximo e percentis de 25 e $75 \%$ de cálcio ionizado, cálcio ionizado estimado, cálcio total corrigido e porcentagem de cálcio ionizado em relação ao cálcio total corrigido pela albumina em cães hígidos

\begin{tabular}{lcccc}
\hline & $\begin{array}{c}\text { Cálcio ionizado } \\
(\mathrm{mg} / \mathrm{dl})\end{array}$ & $\begin{array}{c}\text { Cálcio ionizado } \\
\text { estimado }(\mathrm{mg} / \mathrm{dl}) *\end{array}$ & $\begin{array}{c}\text { Cálcio total corrigido } \\
(\mathrm{mg} / \mathrm{dl})\end{array}$ & $\begin{array}{c}\text { Porcentagem que correspondeu ao } \\
\text { cálcio ionizado em relação ao } \\
\text { cálcio total corrigido (\%) }\end{array}$ \\
\hline Média & 5,41 & 5,41 & 10,83 & 51,00 \\
Mediana & 5,41 & 5,32 & 10,65 & 50,30 \\
Desvio-padrão da média & 0,18 & 0,52 & 1,04 & 5,00 \\
Erro-padrão da média & 0,03 & 0,08 & 0,16 & 0,80 \\
Valor mínimo & 5,04 & 4,15 & 8,30 & 42,30 \\
Valor máximo & 5,78 & 6,45 & 12,90 & 64,10 \\
Percentis 25\% & 5,28 & 5,05 & 10,10 & 47,39 \\
Percentis 75\% & 5,56 & 5,90 & 11,80 & 54,21 \\
\hline
\end{tabular}

* Valor estimado a partir de $50 \%$ do valor de cálcio total corrigido pela albumina e multiplicado por 0,5 .

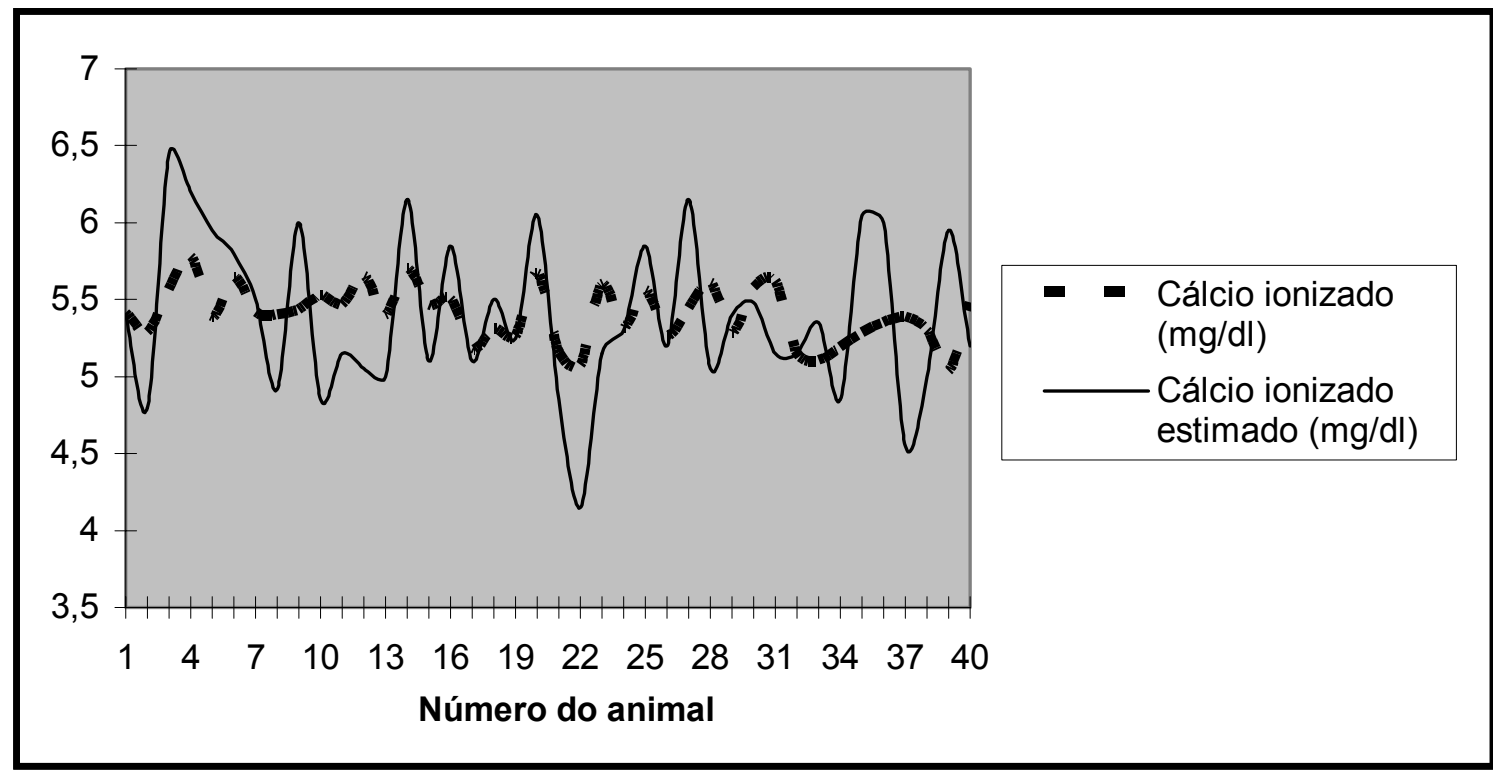

Figura 1. Valores séricos individuais de cálcio ionizado determinado pelo método eletrodo íon-seletivo e de cálcio ionizado estimado obtido a partir de 50\% do valor do cálcio sérico total corrigido em cães sadios. 
Os resultados obtidos sugerem que, para a avaliação adequada do cálcio sérico ionizado em cães sadios, seria necessário usar métodos específicos, confirmando relatos da literatura, em animais que apresentavam enfermidades sabidamente com desequilíbrio do metabolismo do cálcio (Szenci et al., 1988; Agnes et al., 1993; Aroch et al., 1999).

Os valores obtidos poderão ser utilizados para fins de cotejo com os valores a serem obtidos de cães doentes em que a mensuração da parcela biologicamente ativa do cálcio seja importante para o melhor entendimento da patogenia de afecções que comprometem o metabolismo de cálcio.

\section{CONCLUSÃO}

A determinação da fração biologicamente ativa do cálcio (cálcio ionizado), a partir de $50 \%$ em relação ao cálcio total sérico, apresentou baixa correlação em relação ao método eletrodo íonseletivo.

\section{REFERÊNCIAS BIBLIOGRÁFICAS}

AGNES, F.; SARTORELLI, P.; BISSO, M.C. et al. Ionized calcium in calf serum relation to total serum calcium, albumin, total protein and $\mathrm{pH}$. J. Vet. Med. Assoc., v.40, p.605-608, 1993.

AROCH, I.; SREBRO, H.; SHPIGEL, N.Y. Serum electrolyte concentrations in bitches with eclampsia. Vet. Rec., v.145, p.318-320, 1999.

BOWERS, N.G.J.; BRASSARD, C.; SENA, S.F. Measurement of ionized calcium in serum with ionselective electrodes: A mature technology that can meet the daily service needs. Clin. Chem., v.32, p.1437-1447, 1986.

BUSH, B.M. Interpretation of laboratory results for small animal clinicians. 1.ed. London: Blackwell Scientific Publications, 1991. p.350-386.

DUNCAN, R.J.; PRASSE, K.W. Veterinary laboratory medicine clinical pathology. 2.ed. Ames: Iowa State University, 1986. p.181-200.

FELDMAN, E.C. Disorders of the parathyroid glands. In: ETTINGER, S.J.; FELDMAN, E.C. Textbook of veterinary internal medicine. 4.ed. Philadelphia: W.B. Saunders, 1995. v.2, p.1437-1461.
FINCO, D.R. Interpretation of serum calcium concentration in the dog. Comp. Cont. Educ. Pract. Vet., v.5, p.778-786, 1983.

NELSON, W.R.; TURNWALD, G.H.; WILLARD, M.D. Endocrine, metabolic, and lipid disorders. In: WILLARD, M.D.; TVEDTEN, H.; TURWALD, G.H.; Small animal clinical diagnosis in laboratory methods. 2.ed. Philadelphia: W.B. Saunders, 1994. p.147-151.

PORTALE, A.A. Blood, calcium, phosphorus, and magnesium. In: Primer on the metabolic bone diseases and disorders of mineral metabolism. 2.ed. Philadelphia: Lippincott-Raven, 1996. p.87-90.

ROSOL, T.J.; CAPEN, C.C. Pathophysiology of calcium, phosphorus, and magnesium metabolism in animals. Vet. Clin. North Am.: Small Amin. Pract., v.26, p.1155-1201, 1996.

SAMPAIO, I.B.M. Estatística aplicada à experimentação animal. Belo Horizonte: Fundação de Ensino e Pesquisa em Medicina Veterinária e Zootecnia, 1998. 221p.

SARKAR, B.C.; CHAUHAN, U.P.S. A new metode for determining micro quantities of calcium in biological material. Anal. Biochem., v.20, p.155-166, 1967.

SCHENCK, P.A.; CHEW D.J. Determination of calcium fractionation in dogs with chronic renal failure. Am. J. Vet. Res., v.64, p.1181-1184, 2003.

SCHENCK, P.A.; CHEW, D.J.; BROOKS, C.L. Effects of storage on serum ionized calcium and $\mathrm{pH}$ values in clinically normal dogs. Am. J. Vet. Res., v.56, p.304-307, 1995.

SENA, S.F.; BOWERS, G.N.J. Measurement of ionized calcium in biological fluids: ion-selective electrode method. Meth. Enzimol., v.158: A, p.320334, 1988.

SUTTON, R.A.; DIRKS, J.H. Disturbances of calcium and magnesium metabolism. In: BRENNER, B.M.; RECTOR, F.C. The kidney. 5.ed. Philadelphia: W.B. Saunders, 1996. p.1038-1085.

SZENCI, O.; FELKAI, F.; MÄERCZ, I. et al. Ionized calcium, total calcium and acid-base values of blood in healthy and acidotic dogs. J. Vet. Med. Assoc., v.35, p.125-128, 1988.

WATSON, W.A.; DOUMAS, B.T.; BIGGS, H.G. Albumin standards and the measurement of serum albumin with bromocresol green. Clin. Chim., v.37, p.87-96, 1971 . 